\title{
Scientific Journals for Underclassmen
}

\author{
by Sarah H. Jeong
}

$e$ urrently, I am the science reference librarian at the main campus library at Wake Forest University. At the beginning of the semester, faculty members who teach first year seminars have asked me which scientific journals are appropriate for college freshmen and sophomores to read. Scholarly, peer-reviewed scientific journals, which are widely read by faculty, are considered far above the reading level of underclassmen.

It is important for faculty to expose underclassmen to scientific journals, since they may not realize that journals are considered the primary source of information in the natural sciences. Joswick's citation analysis of composition papers revealed that freshmen at Western Illinois University cited more books than journal articles. ${ }^{1}$ She concluded that "books [were] still the most frequently cited source, perhaps because students usually come to college acquainted with the skills required for locating them."2

Beyond LaGuardia's Magazines for Libraries, very little has been published on which scientific journals librarians recommend for underclassmen. LaGuardia’s Magazines for Libraries is a good reference work, which recommends specific scientific journals appropriate for certain reading levels. In Magazines for Libraries, the authors "present over 6500 of the 'best and most useful' periodicals for the general reader."

This article investigates which scientific journals science librarians recommend for underclassmen. The author emailed a survey to the Association of College and Research Libraries-Science \& Technology Section (ACRL-STS) listserv (STS-L@LISTSERV.UTK.EDU) and the Chemical Information Sources Discussion List (CHMINF-L@LISTSERV.INDIANA.EDU), which asked other science librarians for recommendations of scientific journals appropriate for underclassmen. 35 responses from science librarians throughout the United States were received. Table 1 lists scientific journals recommended for underclassmen.

\begin{tabular}{|c|l|c|}
\hline Rank & Journal Title & $\begin{array}{c}\text { Number of } \\
\text { recommendations }\end{array}$ \\
\hline 1 & New Scientist & 9 \\
\hline 2 & American Scientist & 7 \\
\hline 2 & Physics Today & 7 \\
\hline 2 & Science News & 5 \\
\hline 3 & Discover & 5 \\
\hline 3 & Natural History & 5 \\
\hline 3 & Science & 4 \\
\hline 4 & BioScience & 4 \\
\hline 4 & Chemical \& Engineering News & 4 \\
\hline 4 & Technology Review: MIT's National Magazine of Technology \& Innovation & 3 \\
\hline 5 & Nature & 3 \\
\hline 5 & Sky and Telescope & 2 \\
\hline 6 & Astronomy & 2 \\
\hline 6 & Environment & 2 \\
\hline 6 & Geotimes & 2 \\
\hline 6 & IEEE Spectrum & 2 \\
\hline 6 & Journal of Chemical Education & 2 \\
\hline 6 & Journal of the American Medical Association (JAMA) (front section) & 2 \\
\hline 6 & Physics World & 2 \\
\hline 6 & Popular Science & 1 \\
\hline 7 & American Journal of Physics & 1 \\
\hline 7 & Communications of the ACM & 1 \\
\hline 7 & Endeavour & 1 \\
\hline 7 & Environmental Science and Technology & 1 \\
\hline 7 & Isis & 1 \\
\hline 7 & Issues in Science and Technology & 1 \\
\hline 7 & Lancet (front section) & 1 \\
\hline 7 & National Geographic Magazine & 1 \\
\hline 7 & Naturwissenschaften & 1 \\
\hline 7 & New England Journal of Medicine & 1 \\
\hline 7 & Oil and Gas Journal & 1 \\
\hline 7 & Proceedings of the National Academy of Science (PNAS) & 1 \\
\hline 7 & Science Progress & 1 \\
\hline 7 & The Scientist & \\
\hline & & \\
\hline
\end{tabular}




\section{New Scientist}

Table 1. Recommended scientific journals for underclassmen.

This journal is the British counterpart to Science and complements it. It is published weekly. It has recently published feature articles on a wide variety of topics, such as bird flu and nanotechnology. Most of their feature articles are written by science journalists and researchers.

\section{American Scientist}

This bimonthly magazine is published by Sigma XI, the Scientific Research Society. Published since 1913, American Scientist is a generalinterest, non-refereed science magazine. This journal covers a broad range of science topics, such as cancer, astronomy, and ecology. Articles are written by research scientists. There is also an extensive book review section.

The Science section of the New York Times and general news magazines were also recommended by three librarians. In addition, two librarians recommended reading the review articles in the Annual Review series. One librarian commented that "it's a way for students to find out what's going on in the disciplines right now and who the big players are."

Surprisingly, scholarly journals such as Lancet and the New England Journal of Medicine were also recommended. The research articles could be too high above the reading level of underclassmen, but the editorials could be informative.

Another interesting finding is that 79.4 percent of the recommended journals are listed in Magazines for Libraries. This high percentage indicates that many librarians concur with the journal recommendations listed in Magazines for Libraries. It is interesting to note that a significant percentage of respondents agreed on which scientific journals are appropriate for underclassmen. 25 percent of the respondents recommended New Scientist. In addition, 20 percent suggested American Scientist, Physics Today, and Science News.

More research needs to be done on the reading behavior patterns of underclassmen. Which scientific journals are they able to understand and comprehend? Is the content of journals such as New Scientist challenging enough for freshmen and sophomores?

Hopefully, these recommendations will help librarians and faculty encourage underclassmen to read scientific journals. By exposing underclassmen to scientific journals, they will begin to understand the importance of journals in the scientific disciplines.

\section{References}

${ }^{1}$ Kathleen E. Joswick, "Library Materials Use by College Freshmen: A Citation Analysis of Composition Papers," College and Undergraduate Libraries 1(1994): 43-66.

${ }^{2}$ Ibid., 62.

${ }^{3}$ Betty J. Glass, “Most Useful Periodicals,” Library Journal 114(1989): 110. 